\title{
Penerapan Model Problem Based Learning (PBL) dalam Peningkatkan Pembelajaran IPS Tema Panas dan Perpindahannya Tentang Interaksi Manusia dengan Lingkungan di Kelas V SD N 2 Karangsari Tahun Ajaran 2018/2019
}

\author{
1,2,3 Universitas Sebelas Maret \\ indrawati.kurnia0@gmail.com
}

Kurnia Indrawati ${ }^{1}$, Muhammad Chamdani ${ }^{2}$, Joharman ${ }^{3}$

\section{Article History}

accepted 01/10/2019

approved 01/11/2019

published 01/12/2019

\begin{abstract}
This study aimed to describe the application of the Problem Based Learning model to improve social studies learning and improve social studies learning through the application of the Problem Based Learning (PBL) model. This research used a classroom action research (CAR) which was carried out for three cycles. The subjects of this study were the fifth grade students of SD N 2 Karangsari in Academic Year 2018/2019, totalling 31 students. Data collection techniques used were observation, interviews, and tests. The validity of the data used triangulation techniques and sources. Data analysis was carried out through data reduction, data presentation, and conclusion drawing. Based on the results of the study, it can be seen that the average percentage of teacher observation results in the first cycle was $78.32 \%$, the second cycle was $88.06 \%$; and in cycle III it increased to $92.80 \%$. The average percentage of observations of students in the first cycle was $74.72 \%$, the second cycle was $85.72 \%$, and in the third cycle was $90.50 \%$. The percentage of the results of completeness of students' learning outcomes in the first cycle was $69.30 \%$, in cycle II was $85.48 \%$ and in the third cycle was $90.30 \%$. The results of the study indicated that the application of the Problem Based Learning (PBL) model could improve social studies learning with the heat and its transfer theme in the fifth grade students of SD N 2 Karangsari in Academic Year 2018/2019.
\end{abstract}

Keywords: Problem Based Learning, Social Studies Learning

\begin{abstract}
Abstrak
Tujuan penelitian ini yaitu mendeskripsikan penerapan model Problem Based Learning untuk meningkatkan pembelajaran IPS dan meningkatkan pembelajaran IPS melalui penerapan model Problem Based Learning (PBL). Penelitian ini merupakan penelitian tindakan kelas (PTK) yang dilaksanakan selama tiga siklus. Subjek penelitian ini adalah siswa kelas V SD N 2 Karangsari tahun ajaran 2018/2019 yang berjumlah 31 siswa. Teknik pengumpulan data yang digunakan yaitu observasi, wawancara, dan tes. Validitas data menggunakan triangulasi teknik dan sumber. Analisis data dilaksanakan melalui reduksi data, penyajian data, dan penarikan kesimpulan. Hasil penelitian menunjukkan bahwa penerapan model Problem Based Learning $(P B L)$ dapat meningkatkan pembelajaran IPS tema panas dan perpindahannya pada siswa kelas V SD N 2 Karangsari tahun ajaran 2018/2019.
\end{abstract}

Kata Kunci: Problem Based Learning, Pembelajaran IPS 


\section{PENDAHULUAN}

IImu Pengetahuan Sosial merupakan salah satu mata pelajaran yang diberikan sejak SD sampai SMP. National Council for the Sosial Studies (NCSS) (dalam Wahidmurni, 2017) mendefinisikan social studies atau IImu Pengetahuan Sosial sebagai suatu studi yang terintegrasi dari ilmu-ilmu sosial dan humaniora untuk meningkatkan kemampuan warga negara.

Susanto (2016:138) menyatakan hakikat IPS adalah untuk mengembangkan konsep pemikiran yang berdasarkan realita kondisi sosial yang ada di lingkungan siswa, sehingga dengan memberikan pendidikan IPS diharapkan dapat melahirkan warga negara yang baik dan bertanggung jawab terhadap bangsa dan negaranya.

Saat ini pembelajaran IImu Pengetahuan Sosial diajarkan di dalam tema-tema. Penggunaan pendekatan terpadu pada pembelajaran IPS juga menjadi penekanan dalam penerapan kurikulum 2013. Salah satu bentuk penerapan model pembelajaran terpadu adalah adanya tema atau subtema dalam kegiatan pembelajaran. Perwujudan tema-tema inilah yang disebut sebagai konsep pembelajaran tematik.

Hasil observasi dan wawancara pada tanggal 12 November 2018 dan hasil observasi selama magang 3 di kelas V SD Negeri 2 Karangsari ditemukan fakta-fakta yaitu, 1) siswa hanya aktif pada awal-awal pembelajaran sedangkan pada pertengahan sampai akhir pembelajaran siswa sudah mulai melakukan kegiatan yang tidak berhubungan dengan pembelajaran; 2) hanya beberapa siswa yang aktif dalam pembelajaran, misalnya dalam kegiatan tanya jawab yang dikemukan oleh guru; 3 ) siswa sudah lupa saat ditanya kembali materi yang telah diajarkan; 4) pembelajaran masih terpusat pada guru (teaching center); 5) ketuntasan hasil penilaian tengah semester ( PTS ) hanya mencapai $64,1 \%$ atau 19 dari 31 siswa di kelas $V$ dengan KKM 70. Hal tersebut disebabkan oleh beberapa faktor yaitu, 1) pembelajaran masih berpusat pada guru; 2) kurangnya konsentrasi siswa karena minat belajar siswa masih rendah.

Berdasarkan hasil observasi dan wawancara di SD Negeri 2 Karangsari, perlu dilakukan inovasi dan perbaikan pada pembelajaran ilmu pengetahuan sosial agar kualitas pembelajaran meningkat. Salah satu upaya yang dapat dilakukan yaitu dengan menggunakan model pembelajaran yang mengaktifkan serta berpusat pada siswa. Peneliti memilih menggunakan model Problem Based Learning (PBL). Fathurrohman, M (2015:112) menjelaskan bahwa problem based learning adalah pembelajaran yang menggunakan masalah nyata (auntetik) yang tidak terstruktur dan bersifat terbuka sebagai konteks bagi peserta didik untuk mengembangkan keterampilan menyelesaikan masalah, berpikir kritis sekaligus membangun pengetahuan baru. Widiasworo, E (2018:149) menyatakan problem based learning merupakan proses pembelajaran yang menghadapkan peserta didik pada suatu masalah sebelum memulai pembelajaran. Peserta didik dihadapkan pada suatu masalah nyata yang memacunya untuk meneliti, menguraikan, dan mencari penyelesaian.

Pada pembelajaran IImu Pengetahuan Sosial membahas mengenai realita kehidupan sosial dan masalah yang ada di masyarakat. Oleh sebab itu diperlukan model pembelajaran yang tidak hanya membantu siswa dalam menghafal materi, tetapi juga model pembelajaran yang dapat memancing siswa untuk memahami dan menganalisis pada masalah yang ditemukan.

Melalui model Problem Based Learning (PBL) ini diharapkan peserta didik tidak hanya mempelajari ilmu pengetahuan, tetapi juga merasakan karena pembelajaran berkaitan dengan kehidupan nyata. Masalah dijadikan sebagai pemicu bagi proses belajar peserta didik sebelum mereka mengetahui konsep formal. Maka peneliti tertarik untuk melakukan penelitian tindakan kelas yang dilaksanakan kolaboratif dengan guru kelas dengan judul Penerapan Model Problem Based Learning (PBL) dalam Peningkatan Pembelajaran IPS Tema Panas dan Perpindahannya tentang Interaksi Manusia dengan Lingkungan Di Kelas V SD Negeri 2 Karangsari Tahun Ajaran 
2018/2019. Penelitian ini dilaksanakan pada kelas yang sudah menggunakan kurikulum 2013 namun hanya ditentangkan pada materi Ilmu Pengetahuan Sosial saja.

Berdasarkan uraian di atas, dapat dirumuskan masalah sebagai berikut: (1) Bagaimana penerapan model Problem Based Learning ( $P B L$ ) dalam peningkatan pembelajaran IPS tema panas dan perpindahannya tentang interaksi manusia dengan lingkungannya pada siswa kelas V SD Negeri 2 Karangsari tahun ajaran 2018/2019; (2)Apakah penerapan model Problem Based Learning (PBL) dapat meningkatkan pembelajaran IPS tema panas dan perpindahannya tentang interaksi manusia dengan lingkungannya pada siswa kelas V SD Negeri 2 Karangsari tahun ajaran 2018/2019; (3) Apa kendala dan solusi penerapan model Problem Based Learning (PBL) dalam peningkatan pembelajaran IPS tema panas dan perpindahannya tentang interaksi manusia dengan lingkungannya pada siswa kelas V SD Negeri 2 Karangsari tahun ajaran 2018/2019.

Tujuan penelitian ini, yaitu: (1) mendeskripsikan penerapan model Problem Based Learning (PBL) dalam peningkatan pembelajaran IPS tema panas dan perpindahannya tentang interaksi manusia dengan lingkungannya pada siswa kelas $\mathrm{V}$ SD Negeri 2 Karangsari tahun ajaran 2018/2019; (2) meningkatkan pembelajaran IPS tema panas dan perpindahannya fpkus interaksi sosial melalui model Problem Based Learning (PBL) pada siswa kelas V SD Negeri 2 Karangsari tahun ajaran 2018/2019; (3) mendeskripsikan kendala dan solusi penerapan model Problem Based Learning $(P B L)$ dalam peningkatan pembelajaran IPS tema panas dan perpindahannya tentang interaksi manusia dengan lingkungannya pada siswa kelas V SD Negeri 2 Karangsari tahun ajaran 2018/2019.

\section{METODE}

Penelitian ini dilaksanakan di SD N 2 Karangsari yang berlangsung dari bulan Oktober 2018 sampai Maret 2019. Subjek penelitian ini adalah siswa kelas $\mathrm{V}$ yang berjumlah 31 siswa.

Data pada penelitian ini ada dua macam yaitu data mengenai penerapan model Problem Based Learning (PBL) dan data mengenai hasil belajar IPS. Adapun teknik pengumpulan data yang digunakan adalah observasi, wawancara, dan tes.

Teknik uji validitas data pada penelitian ini menggunakan teknik triangulasi yaitu triangulasi teknik dan sumber. Triangaulasi teknik yang digunakan yaitu observasi, wawancara, dan tes. Adapun triangulasi sumber yang digunakan yaitu siswa dan guru. Teknik analisis data yang digunakan dalam penelitian ini yaitu reduksi data, penyajian data, dan penarikan kesimpulan sesuai model analisis data menurut Miles dan Huberman (Sugiyono, 2011: 247)

Indikator kinerja penelitian ini adalah penerapan model Problem Based Learning $(P B L)$ dan peningkatan hasil belajar (KKM = 72) ditargetkan mencapai $85 \%$. Adapun prosedur penelitian ini menggunakan model penelitian tindakan kelas yang terdiri dari empat tahapan, yaitu (1) perencanaan, (2) pelaksanaan, (3) observasi, (4) refleksi.

\section{HASIL DAN PEMBAHASAN}

Penerapan model Problem Based Learning (PBL) untuk meningkatkan pembelajaran IPS tema panas dan perpindahannya pada siswa kelas $V$ SD $\mathrm{N} 2$ Karangsari dilakukan dalam tiga siklus. Setiap siklus terdiri dari dua pertemuan, dengan alokasi waktu 2×35 menit setiap pertemuan.

Pada saat pembelajaran guru menerapkan model Problem Based Learning (PBL) dengan langkah-langkah: (1) orientasi masalah, (2) pengorganisasian siswa untuk belajar, (3) membimbing penyelidikan siswa individu maupun kelompok, (4) penyajian hasil karya, (5) menganalisis dan mengevaluasi proses pemecahan 
masalah. Langkah-langkah pembelajaran ini sesuai dengan langkah-langkah Problem Based Learning (PBL) menurut Arends (Ngalimun, Fauzani \& Salabi 2018: 124-127).

Hasil observasi penerapan model Problem Based Learning (PBL) mengalami peningkatan pada setiap siklusnya hingga mencapai kinerja penelitian yang ditargetkan sebesar $85 \%$.

\begin{tabular}{cccc} 
Tabel 1. Persentase Hasil Observasi Guru dan Siswa \\
\cline { 2 - 4 } $\begin{array}{l}\text { Sumber } \\
\text { Data }\end{array}$ & \multicolumn{3}{l}{ Persentase rata-rata (\%) } \\
\cline { 2 - 4 } & Siklus I & Siklus II & Siklus III \\
\hline Guru & 78,32 & 88,06 & 92,80 \\
Siswa & 75,13 & 85,65 & 90,50
\end{tabular}

Berdasarkan Tabel 1, persentase rata-rata hasil observasi guru pada siklus I yaitu $78,32 \%$. Siklus II meningkat menjadi $88,06 \%$ dan siklus III menjadi $92,80 \%$. Hasil observasi siswa pada siklus I dengan persentase $75,13 \%$, mengalami peningkatan pada siklus II menjadi $85,65 \%$ dan siklus III menjadi $90,50 \%$.

\begin{tabular}{|c|c|c|c|}
\hline & Tuntas (\%) & $\begin{array}{l}\text { Belum } \\
\text { Tuntas (\%) }\end{array}$ & $\begin{array}{l}\text { Rata-rata } \\
\text { Nilai }\end{array}$ \\
\hline Siklus I & 69,30 & 30,70 & 77.02 \\
\hline Siklus II & 85,48 & 14,52 & 85,11 \\
\hline Siklus III & 90,03 & 9,97 & 88.28 \\
\hline
\end{tabular}

Berdasarkan tabel di atas, dapat disimpulkan bahwa ketuntasan hasil belajar siswa mengalami peningkatan. Pada siklus I persentase ketuntasan siswa yaitu $69,30 \%$. siklus II persentase ketuntasan yaitu $85,48 \%$. Sedangkan pada siklus III meningkat menjadi 90,03\%. Berdasarkan hasil observasi dan wawancara, guru berhasil menerapkan langkah langkah model Problem Based Learning (PBL) dan siswa dapat mengikuti pembelajaran dengan baik.

Dengan demikian penerapan model Problem Based Learning (PBL) dapat meningkatkan pembelajaran IPS tema panas dan perpindahannya yang dilihat dari persentase hasil observasi terhadap guru, siswa dan ketuntasan hasil belajar yang memenuhi ketercapaian target dari siklus I-III. Peningkatan hasil observasi terhadap guru,siswa dan ketuntasan hasil belajar IPS dengan menerapkan model Problem Based Learning (PBL) relevan dengan penelitian yang dilakukan oleh Rochimah dan Mujiyono (2015: 70), yang menyatakan bahwa model pembelajaran problem based learning dapat meningkatkan kualitas pembelajaran.

\section{SIMPULAN}

Penerapan model Prblem Based Learning (PBL) dalam peningkatan pembelajaran IPS tentang interaksi manusia dengan lingkungan pada siswa kelas $\mathrm{V}$ SD Negeri 2 Karangsari tahun ajaran 2018/2019 dilaksanakan dengan lima langkah, yaitu: (1) orientasi pada masalah, (2) pengorganisasian siswa untuk belajar, (3) membimbing penyelidikan siswa individu maupun kelompok, (4) Penyajian hasil karya, 
(5) menganalisis dan mengevaluasi proses penyelesaian masalah. Hasil observasi terhadap aktivitas guru pada siklus I mencapai 78,33\%; siklus II = 88,06\%; dan pada siklus III meningkat menjadi $92,80 \%$. Sedangkan observasi terhadap siswa pada siklus I mencapai $75,13 \%$, siklus II = 85,65\%, dan pada siklus III 90,50\%.

Penerapan model Prblem Based Learning (PBL) dapat meningkatkan pembelajaran IPS tentang interaksi manusia dengan lingkungan pada siswa kelas $\mathrm{V}$ SD Negeri 2 Karangsari tahun ajaran 2018/2019. Pernyataan tersebut dapat dibuktikan dengan adanya peningkatan presentase aktivitas guru dan siswa serta peningkatan ketuntasan hasil belajar siswa pada setiap siklus. Hasil observasi terhadap aktivitas guru pada siklus I mencapai $78,33 \%$; siklus II =88,06\%; dan pada siklus III meningkat menjadi $92,80 \%$. Sedangkan observasi terhadap siswa pada siklus I mencapai $75,13 \%$, siklus II $=85,65 \%$, dan pada siklus III 90,50\%. Hasil ketuntasan hasil belajar siswa pada siklus I nilai rata-rata yang diperoleh adalah 77,02 dengan persentase ketuntasan $69,30 \%$. Siklus II, nilai rata-ratanya 85,11 dan persentase ketuntasan $85,48 \%$. Pada siklus III, nilai rata-ratanya 88,28 , dan persentase ketuntasan $90,03 \%$.

Kendala yang dihadapi dalam penerapan model Prblem Based Learning (PBL) dapat meningkatkan pembelajaran IPS tentang interaksi manusia dengan lingkungan pada siswa kelas V SD Negeri 2 Karangsari tahun ajaran 2018/2019, yaitu: (1) siswa tidak tentang ketika merumuskan hipotesis; (2) suara presentator kurang keras sehingga tidak terdengar dari belakang; (3); membutuhkan banyak waktu saat diskusi. Adapun solusi yang diberikan peneliti dari adalah: (1) siswa diberikan waktu untuk persiapan sebelum pembelajaran dimulai; (2) guru melakukan pengondisian kelas secara menyeluruh; (3) mengingatkan guru untuk memperhatikan waktu pembelajaran yang telah direncanakan.

\section{DAFTAR PUSTAKA}

Wahidmurni. (2017). Metodologi Pembelajaran IPS. Yogyakarta: Ar-Ruzz Media.

Fathurrohman, M. (2015). Paradigma Pembelajaran Kurikulum 2013. Yogyakarta: Kalmedia.

Sugiyono. (2011). Metode Penelitian Pendidikan Pendekatan Kuantitatif, Kualitatif, dan $R \& D$. Bandung: Alfabeta.

Ngalimun, Muhammad \& Salabi. (2015). Stategi dan Model Pembelajaran.Yogyakarta: ASWAJA PRESSINDO.

Rochimah, A \& Mujiyono. (2015). Peningkatan kualitas pembelajaran IPA melalui model pembelajaran Problem Based Learning. Joyful Learning Journal, 4 (3), 70. $\begin{array}{lllll}\text { Diperoleh } & \text { pada } & 29 & \text { Maret } & \end{array}$ https://journal.unnes.ac.id/sju/index.php/ili/article/view/8401.

Widiasworo, E. (2018). Strategi Pembelajaran Edutainment Berbasis Karakter.Yogyakarta: Ar-Ruzz Media.

Susanto, A. (2016). Teori Belajar dan Pembelajaran di Sekolah Dasar. Jakarta: Kencana Prenadamedia Group. 